\title{
Capitalism, Globalisation and the Underdevelopment Process in Africa: History in Perpetuity
}

\author{
Akinpelu O. Olutayo* \\ \& Ayokunle O. Omobowale**
}

\begin{abstract}
Since the incorporation of the Third World nations into the world capitalist system, the underdevelopment process seems to have commenced through the use of liberal economic principles. In spite of the obvious pauperisation of these nations, it seems as if there is no alternative even when indigenous governments are in control of affairs. This paper attempts to show why the underdevelopment process has persisted with capitalism entrenched in the garb of globalisation. It suggests that the way out is for the developing world to control and own their means of survival without which the underdevelopment process shall continue. Of utmost significance however is the need to control the intellectual domain.
\end{abstract}

\section{Résumé}

Le processus de sous-développement semble avoir commencé depuis l'intégration des nations du Tiers monde dans le système capitaliste par le biais de l'utilisation des principes de l'économie libérale. Malgré la paupérisation évidente de ces nations, il semble qu'il n'y ait pas d'alternatives même quand des gouvernements autochtones sont aux affaires. L'étude tente de montrer pourquoi le processus de sous-développement persiste avec la complicité du capitalisme retranché dans les habits de la mondialisation. Elle suggère que l'issue pour les nations du Tiers monde est de contrôler et de s'approprier leurs moyens de survie sans quoi le processus de sous-développement va

* Department of Sociology, Faculty of the Social Sciences, University of Ibadan, Nigeria. E-Mail: lantopamtu@yahoo.com

** Department of Sociology, Faculty of the Social Sciences, University of Lagos, Nigeria. E-mail: muyiwaking@yahoo.com 
inévitablement perdurer. Toutefois, la nécessité de promouvoir le savoir est d’une importance capitale.

\section{Introduction}

The interconnectedness between the past, the present and the future, often encapsulated in the study of history, helps to highlight alternative development perspectives available to a nation or society. Ironically, however this does not seem to be the case for most societies, including Nigeria. The development patterns that have been used so far are those being dictated from outside their shores without any historico-sociological content. Unfortunately, these developmental orientations have been moulded and remoulded in various ways without any positive oriented outcome. Unfortunately, the remoulding process continues without fundamentally changing the basis of the argument.

Except for a brief interjection of the socialist alternative to development in some parts of Africa, the capitalist model has continued to hold sway. In this capitalist model is the assumption of the market as the means and end. Characteristic of these means and ends are the ideas of individualism, subjectivism and naturalism embedded in the neo-classical (neo-liberal) political economic theory (Onimode 1977). The individual is perceived as a rational being and the subjective interpretation of his action, without the cultural context - in Weber's definition of social action - is enough to understand homo economicus, 'economic man'. In this economic thinking, man is interested in making profit with societal interest as his focus because, to neoclassical economists she or he is informed by the need to satisfy human wants and not needs. Thus, the scarcity of these wants is the motivating factor for production and exchange. Since 'human wants are insatiable', production would naturally be the motive and it is only through the free market economy of demand and supply that profit becomes feasible.

According to Onimode (1977: 5), such simplistic explanations of political economy governed the material culture that incubated and nurtured neoclassical economies in the industrial capitalism of Britain, Western Europe and North America in the fourth quarter of the nineteenth century. It was also this rationality that somewhat justified the colonisation and exploitation of the Third World countries during this period. The assumption here was that the Third World countries would, naturally, follow the development path of their colonial overlords without any recourse to their socio-historical circumstances. It was indeed, Modernization by Design (Morse et al. 1969).

Ironically, more than a century after this experiment, the underdevelopment process has continued to intensify while the prescription for the disease of underdevelopment has not changed. Even when it is glaring that the 
majority of the so-called developing countries cannot withstand the competition characteristic of the capitalist world order, due to the 'survival of the fittest' syndrome, the IMF, the World Bank and the World Trade Organisation (WTO) have continued to forcefully integrate them into the global economy. Oswald de Rivero (2001: 5-6) postulates that:

The prosperity and the development of all countries will be achieved this time, as a result of worldwide competition within a totally unfettered global market. Such a belief, with its utopian ingredients, presents globalization as an unstoppable process, beyond human control, as though it were the universal law of gravity - in escapable for persons, for enterprises, and even for nations.

This kind of reasoning informed colonialism and the process is repeating itself in what is now referred to as 'globalisation' even when the 'skin' and the 'voice' are quite identical. It was the 'unfettered access' that necessitated the 'scramble' for Africa and the same 'unfettered access' is making the second 'scramble' possible even when, as Oswaldo de Rivero (2000) further showed, the United States, Europe and Japan never indeed allowed such unfettered access in their development experience. During their development processes, these nations protected their young industries and copied each other's technology.

Today, such may be impossible! As it was in the colonial era, so it is today, and if the situation persists, it may be forever. This repetitive history is what the paper attempts to show in the remaining sections. Section II briefly presents the process of the 'capturing' of 'Africa' and its incorporation into the world capitalist economy under the neo-classical or neo-liberal political ideology. On the basis of the historical experience of the colonial overlords and the need to ensure a free and unfettered access to the colonies by the colonial traders and merchants, state capitalism was recommended as the development paradigm for the newly independent African states. The independence era, which is the third section of this paper, explains the hiccups in the relationship between the elites, on whom governance devolved and the colonial overlords, leading to 'indigenisation' and nationalisation in some cases and even outright rejection of the capitalist ideology in others. With 'glasnost' and 'perestroika' resulting in the collapse of the socialist regime and the triumph of capitalism, the second onslaught began in earnest with the globalisation pandemonium. Section IV exposes how this process is being executed and how it ensures the unfettered access to the underdeveloped economies in a return to neo-classical ideology. The final section summarises the conclusion. 


\section{Africa in the world capitalist economy}

That Africa entered into the world capitalist economy with a peripheralsatellite status has been succinctly shown by Marxist and dependency theorists since the mid-twentieth century, starting with Baran (1957) in his Political Economy of Growth. What is of significance, however, is the diversity of cultures and peoples indigenous to Africa, which were forcefully brought together. The word 'African' can therefore be misleading if it includes more than the persons who do not identify themselves with that continent. The histories of these peoples were annulled by the process of incorporation, hinging on the 'assumption' that Africa had no history (Roxborough 1979; Ajayi 1997; Mazrui 1997). Mazrui (1997: xxxv) asserted that for about twothirds of the twentieth century during the colonial period, the understanding of Africa was inhibited by four great denials, including the denial of history, the denial of science, the denial of poetry, and the denial of philosophy (including religious philosophy). Such denials, even if only of history, as Ajayi (1997:xxxiii-xxxiv) has posited, 'imply the denial of humanity and vitiate all expectations of development'. It is not surprising therefore that development was (is) to be conceptualised on the basis of foreign history. It is seen as a forward march towards the 'Western' model. This conceptualisation was not a theoretical construct but purposely and consciously designed by colonial overlords. From the 'Dark Continent' illusion, the idea was (still is) to give 'light' or 'civilisation' to those living in 'darkness'. The Christian ideology was therefore a plausible instrument even when the bearers of 'light' might not be 'Christians' (see Olutayo 1991). The ideology was used to encourage slavery and later, for its abolition even when capitalism was the ultimate aim as clearly enunciated in 'The Bible and the Plough'. Indeed, the 'Paper Treaties' signed by the different occupying European countries towards the end of the nineteenth century to justify free assess clearly show the depredation of these nations. The 'Papers' were often termed 'Treaties of Protection' from the other 'invading' European nations. The competition for space in Africa led to what is referred to as the 'Scramble for Africa', necessitating foreign negotiations for Africa's lands and peoples and the eventual colonisation.

\section{Africa in the colonial context}

The Colonial Development and Welfare Act (1940) represents perhaps the first and only document that clearly stated the colonial development policy for British Africa. It was an improvement on the process of 'borrowing' from the Colonial Development fund set up with the Act of 1929 for the West Indies through grants or loans for 'economic development' in the colo- 
nies. Essentially, the Fund was to 'promote commerce with, or industry in, the United Kingdom' - an end which it was hoped to achieve 'by assisting the development of agriculture and industry in the colonies'. ${ }^{1}$ Promoting commerce with or industry in the UK was ensured through the importation of agricultural raw materials from the colonies. It was when the required supply was not enough that the Act was modified to include 'any purpose likely to promote the development of resources of any colony or the welfare of its people'. ${ }^{2}$

Fundamentally, trade and thus production for the market, being the basis of the British economy, was an important stage in their historical development. Indeed for most of Western Europe and North America, the technological revolution, mostly in the nineteenth century, already gave them the economic power over land, sea and air with highly developed means of production. Arising from this situation were certain relations of production characterised by capital-labour relations of a wage system and the owners of capital being the controllers of the political superstructure in a liberal democracy. The control over the economy and politics also gave the owners control over the educational state apparatus, having destroyed the basis of the family in the pre-capitalist social formation. It was, in fact, a fundamental transformation of the pre-capitalist social structures which gave birth both to a new understanding of the economy and the emergence of sociology as a discipline to explain the causes(s) of this transformation and the basis of the 'new order'.

Consequently, the paradigms that the founding fathers of sociology introduced constituted a comparison between the 'old' and the 'new', tradition' versus 'modernity', rural versus urban etc. Since this was what the historico-sociological experience of European societies involved; their sociology was so presented. Yet it was also clear that the European nations did not go through the same historical experience both in terms of time and the overall fundamental impact of the technological revolutions on their different societies (Olutayo 2001; Giddens 1971). The inequality and poverty resulting from the new arrangement necessitated certain welfare programmes to reduce the negative impact on society.

In spite of these, and without a critical examination of the African situation, these paradigms were foisted on Africa. 'Urban', 'Gesellschaft', 'modern' societies of Europe were to be replicated in Africa through the 'cloning' of like institutions in Anglophone Africa, and the Colonial Development and Welfare Act was the policy document. By the time the policy was introduced, Africa was not to be treated as the White Man's Burden (Gann and Duignan 1967). Africa was expected to fend for itself through the volume of trade (exclusively with the UK) and the revenues that could be generated 
through taxation in the colonies. To increase the volume of trade, roads and railways were constructed ${ }^{3}$ through forced labour. Where this was not effective enough, heavy taxation was imposed (especially during the First and Second World Wars. ${ }^{4}$

Generally, the enhancement of trade and commerce involved private foreign merchants and shippers (exclusively British) employing indigenous intermediaries who understood the people's way of life (See Shenton [1986] on the United African Company and Olutayo [1991] on the Elder Dempster Shipping line). The Colonial Administrators were to assist these merchants and shippers who, in turn, paid taxes to the administration. Prices of goods were fixed though the free market economy (laws of demands and supply) so colonial revenues were always fluctuating. Closer to reality was the fact that the higher prices of industrial goods imported into the colony affected the prices of raw materials, which the colonies exported based on the comparative advantage theory (Olutayo 1991). As such, in its entire ramification the colonialists dictated events in the colonies. The indigenous were to 'learn the ropes' of these exploitative processes. Lord Lugard (1922: 5) in his Dual Mandate explicitly stated that the administration was: To inculcate in the natives a sense of individual responsibility of liberty, and of justice and to teach their rulers how to apply these principle... ${ }^{5}$

Until it became obvious that colonialism would collapse, indigenous entrepreneurs were not found suitable enough to replace the Europeans. By the mid-1950s, private indigenous enterprises began to emerge. However they were under the control of the state, which created them. Gradually, also, indigenous political elites started to emerge, tutored in European ways of governance. Due to the lack of confidence in indigenous traders, or, perhaps more because European merchants - who later moved into manufacturing and whose industry had to be protected, especially because of their relevance to Europe and the United States - state capitalism had to be the mode of governance. This was however a superstructural arrangement as private enterprises were to be encouraged. Perhaps of more significance is the fact that governments the world over had to play immense roles in macroeconomic planning and management to solve the economic problems which characterised the Great Depression of the 1930s using the prescriptions of Keynesian economics. Thus most African nations used this model of state capitalism recommended to them by their colonial overlords (Nzenwe 1988: 3). Nonetheless, special financial incentives were given to both indigenous and foreign private enterprises with the provision of social infrastructures exclusively by the state. In many cases, government services and parastatals employed most of the citizens, in line with the Keynesian Model, in the health, education, housing, water and electricity supply, posts, rail, air and sea trans- 
portation sectors (Onimode 1988: 35) as well as the marketing of agricultural produce through marketing boards. It is important to reiterate here that the marketing boards were created to ensure the steady supply of raw materials to colonising countries for their industrial development under the guise of the law of comparative advantage.

\section{Africa in the neo-colonial context}

For most of Africa, there was a carryover of colonial institutions and structures into 'flag independence'. Apart from the intellectual doctrines - which manifested themselves even during the existence of the two separate world ideologies - Africans were fundamentally oriented towards culture, popularly referred to as the total ways of life, of their colonial overlords. Though it has been argued by some authors (for example, Curtin 1972) that it was not a process of wholesale enculturation. The basis of African economy was essentially outside the grasp of Africans. While some superstructural elements exist as African, the basis of survival is disjoined from these superstructures.

For instance, state capitalism was not only carried over into the independence era, the means of production were also not of indigenous creation. Indeed, the capitalist ventures in which the state invested were mainly revenue generating in nature rather than for the fundamental transformation of the social structure. This is not surprising since the market-controlled economy was already the vogue in the former colonising nations. Thus the problem was how to industrialise so as to 'catch up' with the former overlords - the more so when 'modernisation by design' was recommended by the international financial institutions made up of the IMF, the UN and the World Bank. Even the world ideologies of socialism and capitalism recommended technological transfer rather than the creation of technology without recourse to the history of these ideologies and the role technologies played in the development of their economies.

In the capitalist nations, a return was made to Adam Smith's classical two century-old thesis. They opened their economies to market forces, and the neo-colonial economies were made to follow suit. Indeed, this was the case for all of Western Europe's former colonies and Liberia, which was under American 'protection'. For those nations under the socialist influence of the USSR, the control of the economy was indirectly under the Soviet regime but the state controlled the market (not a free market economy). In other words, the aim of the socialist states was not profit making but production for the satisfaction of the needs (not wants) of the society. As such, they attempted to create their own technologies for the production of the needs of the majority of the people, who were directly involved in the crea- 
tion of these technologies. Consequently, distribution of products was, relatively, on an equal basis. Perhaps this was more realistic in the USSR than in their African appendages because the technologies were imported from the former to the latter rather than the indigenous creation of their own technologies.

More apt, however, is the experience of African nations with capitalist orientation. Apart from the importation of capitalist industrial technologies, inequality was very manifest in the relationship between the foreign and indigenous industrialist and entrepreneur. The structured inequality is such that the former has better access to finance and industrial capital than the latter, yet the former is more interested in repatriating profits back abroad than the latter. Thus the effects of foreign companies are more strongly felt outside their source(s) of profit since little is ploughed back into the economy. On the other hand, the indigenous capitalists, having secured aids, grants and loans from the government, are compelled to plough back their profits into the economy. Ironically, even their industrial capital is imported, thus they also create markets for foreign companies. Consequently they are at a disadvantage (see Coughlin 1988: 143-163 for the Kenyan experience).

Interestingly, even with the disadvantage, finance capital still remains the means by which African governments attempt to develop. With the indigenisation and nationalisation and the setting up of parastatals in the late 1970s for example, it became clear that these indigenous companies could not compete effectively with the foreign ones. As such most African countries experienced de-industrialisation in the 1980s (Stein 1992; Moseley 1992; Wilson 1990). Botswana which relies on and encourages and promote indigenous, foreign, and jointly owned enterprises without nationalising or indigenising has been able to add value to manufacturing and increase citizen participation in the manufacturing sub-sector. Yet, as Valentine (1993: 31, pdf version 2001) shows, the industrial policy, relying 'merely on finance' (Financial Assistance Policy) cannot meet the full range of enterprise development problems. She asserts that 'Non-financial assistance in the form of managerial and technological assistance may be of great importance in raising the likelihood of success of citizen-owned enterprises, and assisting in raising enterprises out of their infancy' (p. 31). Indeed for Nigeria, although the relevance of the creation or at least internally managed imported technology to improve the quality of life of people is acknowledged, the science and technology policy of 1987 has not created any serious research and development activity to develop indigenous technology to produce a variety of locally made goods. Rather, finished technologies continue to be imported (Davies 1998: 158). In Botswana, as acknowledged in her fourth and sixth National Development Plans, the economy is characterised by gross 
inequalities and lack of diversification. The majority of the rural dwellers and forty percent of the urban dwellers are living in absolute poverty. The economy, though export driven, relies mainly on a depletable mineral resource - diamonds. As Mhone (1996) has shown, Botswana is experiencing economic growth without economic development and equity. Mhone (ibid: 98) concludes that:

Trickle-down effects of the fast growing free market in Botswana have certainly failed to slip through to the bottom. While ... financial strategy may be good advice to an individual who has a financial windfall ... (it should be clear that) the present pattern of market-determined resource allocation in Botswana ... would merely be another addition to the economic windfall of the Botswana government and its elite ... unless nonmarket policy interventions are developed to ensure that the benefits reach the majority at the bottom.

\section{Globalisation, Africa and development}

Although the process of globalisation for Africa started with its incorporation into the world capitalist system on the periphery, the conspiracy of the International Monetary Fund (IMF) and the World Bank signalled a major onslaught in effecting a 'long-term' strategy for transforming the African social structure (Stein 1992). Such transformation strategy hinges on a rational-deductive methodology and, therefore, a perpetuation of the modernisation by design and the civilising mission thesis (Onoge 1995) of the colonial period. It locates the problems of development in the failure of internal process and structures (Olutayo and Bankole 2002; Olutayo 1991) with the assumption that human beings are rational with predictable behaviour as epitomised in Weber's 'ideal type'. In this strategy is a return to the neoclassical model, which assumes that a free market economy will automatically lead to indicators that reflect scarcity and choice. That is, ceteris paribus, the free reign of the market will lead to efficient choice on what and how to produce, which are indicative of societal resource endowments. It is a way to introduce the trend in the American and Western Europe's perception and way of life into Africa and the rest of the world (Nyerere 1998: 14; Hammouda 1999: 74).

In the 1980s, the IMF and World Bank presented a unified package, often in the form of an Economic Recovery Programme, as a condition for African countries to find a way out of the debt crisis. Central to this package is the rolling back of the state from the control of the economy, and encouraging rather a facilitator role. State capitalism that was endorsed in the colonial and the latter part of the 1960s is now perceived as a hindrance to development. In laying greater emphasis on market forces for the allocation of re- 
sources, some of the policies that most African countries have now endorsed (since the 1980s) include: (a) removal of government subsidies and price controls; (b) significant devaluations; (c) cuts in public expenditure with deep public sector retrenchments; (d) privatisation; (e) relaxation of foreign exchange controls (f) an increase of interest rates to real levels; (g) the withdrawal of protectionist measures; and (j) an increase in agricultural producer prices.

By 2002, the Human Development Index measured in terms of life expectancy, educational attainment and adjusted real income by the United Nations Development Programme (UNDP) showed that only Mauritius (ranked 64 out of 177), Cape Verde (105), Equatorial Guinea (109) and South Africa (119) are in the top two-thirds of the UNDP's assessment. Most other rank 'low' with Burundi, Niger, Burkina Faso, Mali and war-ravaged Sierra Leone (most in the West African region) occupying the bottom positions. Even when Nigeria had not obtained any fresh loans since 1999, the debt stock increased from US\$30.99 billion in 2003 to US\$32.9 billion in 2004 (African Review of Business and Technology, September, 2004: 6).

Indeed, as Hammouda (1999: 74) has shown, the effect of the Structural Adjustment Programme (SAP) is an 'ambivalence between two societies: on the one hand, a modern society, ... integrated in increasingly globalised models of production and consumption, and on the other, a field of ruins spreading from Cairo suburbs to Algiers; from the Burundi and Rwanda countryside, where the world of marginality and exclusion extends, where violence, diseases, and drugs take their toll'. It is expected, as in modernisation theory, that there will be a trickle-down from the 'modern' to the 'pre-modern'- an assumption that did not earlier materialise. Insofar as the free market necessitates the creation of surplus profit, concern for the under-privileged who are always in the majority is out of the question. As Ake (1994: 4) posits in his 'Democratization of Disempowerment in Africa', since the IMF recommends liberal democracy which concentrates on formal pluralism of multi-parties and electoral competition, the ruling groups' organising principle can only be formal freedom, formal equality, respect for private property and government by consent rather than conmmunitarian bonds and values of the majority of the African population who are rural. As such a free market economy will not touch on their real material and cultural needs.

\section{Conclusion}

Recourse to history in perpetuity has been possible because the 'North', with the end of the Cold War, is able to control the IMF and the World Bank. Such control was and is possible because of the North's technological, financial and political strength vis-à-vis the 'South'. By the 1990s therefore, a 
'new world order' emerged in which the super powers, under the leadership of the United States, could ride rough-shod over others in world affairs (South Centre 1992). The First Gulf War and the overthrow of Saddam Hussein in 2003 clearly show that the super powers can bring any dissenting nation into line. Indeed, the counter-revolutionary activities of Western intelligence agencies are no longer so hidden (see Ntalaja 1987 for the case of southern and central Africa), but constitute a blatant violation of the independence of other nations.

Of very great consequence, however, is the intellectual domination of the South by the North. Today scholarships and grants are awarded in order to influence the economic development of Africa through sponsored and predetermined thematic research. Thus intellectuals are brought in line to conform with the North's perception. With this, technologies are imported and the intellectuals only become 'repairers' of these technologies rather than creators and innovators. Not only technologies, ideas about the 'ideal' way of life become North-centred such that a 'colonial mentality' persists. Insofar as this continues, the underdevelopment process will persist.

Put succinctly, the problem of underdevelopment in Africa has persisted because the paradigm within which development is being sought has not changed. Indeed, as Hopkins and Wallerstein (1996) summarised, the modern world capitalist system, which began in the sixteenth century and still persists today, is structured by six vectors which are mutually independent. These vectors - an interstate system, world production, world labour, world human welfare, social cohesion of states (nationalism), and structures of knowledge - perpetuate inequality with the US leading the dominant hegemonic structure over the Third World nations. In this unequal arrangement, nurtured by Newtonian science and liberalism, the oppressed and disadvantaged are sermonised with the idea of an

Inevitable triumph of an incrementalist convergence in human welfare as well as the eventual virtual elimination of violence that would result ... precisely from the increasing cohesion of the state resulting from lessening of inequality (Hopkins and Wallerstein 1996: 7).

Ironically, this inequality continues to deepen and violence prevails, as human conditions are typified by poverty, misery, and frustration. The world is continually being challenged to solve these problems but the dominant structures, being preserved, albeit in various forms, by the benefiting nations, continue to predominate in a rhythmic fashion. As historical systems have shown however, this cannot continue forever because

... there must come to a point when the trends create a situation in which the cyclical rhythms are no longer capable of restoring long-term (rela- 
tive) equilibrium. When this happens we may talk of a crisis, a real 'crisis', meaning a turning point so decisive that the system comes to an end and is replaced by one or more alternative successor systems. Such a 'crisis' is not a repeated (cyclical) event. It happens in the life of any system, and signals its coming to an end. And it is not a quick event but a 'transition' ... (ibid: 8).

Such a 'transition' seems to have matured around the late 1960s when the foundation and relevance of 'science' were effectively questioned regarding its ability to deliver the inevitability of progress and prosperity for all.

In the social sciences, this criticism began with the dependistas who countered the idea of the inevitability of progress propounded by modernisation theory. They showed that on the contrary, underdevelopment is the result of the relationship between unequal partners in any exchange. Thus 'science' as the liberating principle ensuring 'progress' from rural to urban, or tradition to modernity or underdevelopment to development, is a ruse (for details on the subordination of 'science', see Lee [1996: 178-206]). Yet the idea continues to hold sway as the debt crisis in Africa, necessitated by her peripheral status in the modern world capitalist system, implies that this exploitation will persist. Ironically, at the intellectual level in the university, where the realisation of this strategy seemed apparent in the 1970s, the resulting coercion of the state (as it is pushed to withdraw from funding higher education) has weakenened the academic unions such that there seems to be a collusion of the intellectuals with the state regarding restructuring. Entrepreneurial education, for example, being sponsored by international organisations (mainly US and Western Europe), is the new orientation with a view to lessening the 'burden' of the state as the largest employer of labour. It is, thus, part of the World Bank conditionality that is being satisfied.

Of significant interest, however, is the empirical evidence showing that the structure of the modern world system will only continue to perpetuate the underdevelopment process. The attempt to create entrepreneurs in Africa is not a new phenomenon. The colonialists started it. The independent states continued it, yet the result is glaring enough - failure! Such failure, again, at the risk of over-emphasis, is inevitable in a capitalist system, which thrives on inequality. In this structural arrangement, those who own or control the means of production are better able to accumulate capital (Ikeda, 1996). Entrepreneurial education therefore further requires the ability to own or control the means of production in the market economy. To be able to do this, for Third World entrepreneurs, means the ability to control consumption patterns which only the state can ensure. Yet the state is incapacitated due to the interstate system of the global economy characterised by the 
removal of trade barriers for the global flow of manufactured goods under the General Agreement on Tariff and Trade (GATT). Consequently, the first level at which independent development can be assured is in the intellectual domain. Even though the initiative came from the 'North' due to intellectual crisis, and rather than resulting in contradictions and crisis, as Obono, (2004: 88) seems to posit, postmodern thoughts, beginning with the emergence of what was once referred to as 'everyday sociology' (Olutayo 2001-2002), the non-rational (or is it irrational) basis of scientific sociological theorising is exposed. Today, contextual analysis with emphasis on the socio-cultural milieu, rather than a generalised theory for all societies is the emerging framework for understanding societies. It was the generalised theory of society that informed the emergence and application of structural-functionalism (even in radically structured theory of Marx which attempted to subordinate the relevance of Marx's mode of production), and social action theories as the legitimate framework for understanding all societies.

The application of these theories resulted in an assumed linear development pattern characterising the underdeveloped societies in their expected movement towards the model of the developed nations. Basically, this is the manifestation as history is being repeated in the extended capitalist garb of globalisation and the continued underdevelopment of Africa. This historical trend can be broken intellectually through contextual analysis as shown in the Concept of Mode of Production in the Analysis of Development (Olutayo 2002). Otherwise what Onimode (1987: 30) refers to as 'bankrupt manipulative tools' which have misled African governments will continue to subsist. He states that it is only when this 'bankrupt scholarship' is combated and replaced by 'progressive scholarship' that socio-historical understanding of the societies become clearer and, therefore, the opportunity opens up of offering alternatives to governments. This may only be possible when Africans own and control their means of survival and produce in response to their survival needs. This will impact directly on African culture in such a way that knowledge dependence in language, dressing, information technology and so on will gradually wither until Africa becomes truly emancipated. For its realisation, the social life of the people becomes central. That is the environmental circumstances and social context are foundational to development. For instance, and with respect to the latter, information technology is foreign-language based. Until it is possible to invent IT based on African languages, development will be dependent.

The second level, of course, is for the government to appreciate the genuineness of this new research and theoretical orientation. This can only be a gradual process as the present situation is that of a 'dried fish' that 
cannot be bent. As students are turned out with this new orientation, it is to be hoped that a new way of doing things will emerge, because of the immense influence of society on educational institutions. For African intellectuals whose ideas are not often taken seriously except when viewed against the 'western' paradigm, the need is to begin to create their own structures of knowledge relevant to their societies. Such creations are possible when existing indigenous knowledge systems are reassessed. These knowledge systems are the 'myths' and 'superstitions' surrounding the explanations about their existence that require new interpretations. This was what characterised the emergence of the modern world systems in the sixteenth century wherein new interpretations were given to philosophy and theology, thus separating the spiritual from the temporal (Shayegan 1992: 18; Hopkins and Wallerstein 1996: 7).

\section{Notes}

1. 'Statement of Policy on Colonial Development and Welfare' in Supplement to Gazette No. 11 of 17 March 1940 (Presented by the Secretary of State for the Colonies to Parliament by Command of Her Majesty, February 1940).

2. Cmd 672, 'Colonial Development and Welfare Act: Report on the Use of Funds Provided Under the Colonial Development and Welfare Acts, and the outline of the proposal for exchequer loans to the Colonial territories' (Presented by the Secretary of State for the Colonies by Command of Her Majesty, February 1959), London: Her Majesty’s Stationery Office.

3. C.S.O. 1/32, No. 123, 10 February, 1914.

4. Cmd 6175op cit.

5. Since Lugard, or even perhaps before, the creation of a dependent nation/ continent through colonialism was the aim; colonialism was thus the nonrecognition of, or a rejection of, the hitherto existing culture; hence a need to superimpose a supposedly 'new'/'better' way of life.

\section{References}

Ade Ajayi, J. F., 1997, 'Africa in Perspective', in Middleton, J., Ade Ajayi, J. F., Hyden, G., Miller, J. C., Shack, W. A., Watts, M., eds., Encyclopedia of Africa South of the Sahara, New York: Charles Scribner and Sons.

African Review of Business and Technology, September 2004, p. 6.

Ake, C., 1994, Democratization of Disempowerment in Africa, CASS Occasional Monograph No. 1, Lagos: Malthouse.

Baran, P., 1957, The Political Economy of Growth, New York: Monthly Review Press.

Coughlin, P., 1988, 'Development Policy and Inappropriate Product Technology: The Kenyan Case', in Coughlin, P. and Gerrishon, I., eds., Industrialization in Kenya: In Search of a Strategy, Nairobi: Heinemann. 
Curtin, P. D., 1972, 'Introduction', in Curtin, P. D., ed., Africa and the West: Intellectual Responses to European Culture, London: University of Wisconsin Press.

Davies, A. E., 1998, 'Government Policy on Technological Development in Nigeria: An Appraisal', Africa Development, Vol. XXIII, pp. 143-160.

Gann, L. H. and Duignan, P., 1967, Burden of Empire: An Appraisal of Western Colonialism in Africa South of the Sahara, London: Pall Mall Press.

Giddens, A., 1971, Capitalism and Modern Social Theory: An Analysis of Marx, Durkheim and Max Weber, Cambridge: Cambridge University Press.

Hammouda, Hakim Ben, 1999, 'Rethinking Bretton Woods from an African Perspective', CODESRIA Bulletin, Nos. 3 and 4, pp. 71-80.

Hopkins, T. and Wallerstein, I., 1996, 'The World System: Is There a Crisis?', in Hopkins, T. and Wallerstein, I., eds., The Age of Transition: Trajectory of the World System, 1945-2025, London and New Jersey: Zed Books, pp. 1-10.

Ikeda, S. S., 1996, 'World Production', in Hopkins, T. and Wallerstein, I., eds., The Age of Transition: Trajectory of the World System, 1945-2025, London and New Jersey: Zed Books, pp. 38-86.

Lee, Richard, 1996, 'Structures of Knowledge' in Hopkins, T. and Wallerstein, I., eds., The Age of Transition: Trajectory of the World System, 1945-2025, London and New Jersey: Zed Books, pp. 178-206.

Lugard, F. D., 1922, The Dual Mandate in British Tropical Africa, Edinburgh and London: William Blackwood and Sons.

Mazrui, A. A., 1997, 'The Study of Africa: Genesis, Substance, and Cultural Boundaries', in Middleton, J., Ade Ajayi, J. F., Hyden, G., Miller, J. C., Shack, W. A., Watts, M., eds., Encyclopedia of Africa South of the Sahara, New York: Charles Scribner and Sons.

Mhone, G., 1996, 'Botswana Economy still an Enclave', Africa Development, Vol. XXI, Nos. 2 \& 3, pp. 89-99.

Morse, C., Ashford, D.E., Bent, F. T., Friedland, W. H., Lewis, J. W., and Macklin, D. B., 1969, Modernization by Design: Social Change in the Twentieth Century, Ithaca and London: Cornell University Press.

Moseley, K. P., 1992, 'West African Industry and Debt Crisis', Journal of International Development, 4 (1), pp. 1-27.

Nyerere, J. K., 1998, 'Are Universal Social Standards Possible?’, South Letter, Vols. 2 \& 3, No. 31, pp. 14-17.

Ntalaja, Nzogola 1987, 'The Crisis in Zaire’, in Nzogola Ntalaja, Bade Onimode, Bernard Magubane, Harold Wolpe, Kempton Makamure, Fatima Babniker Mahmoud and Adoulaye Bathily, eds., Africa's Crisis, London: Institute for African Alternatives.

Nzenwe, U., 1988, 'Nigeria: The Limits of Privatization in a Developing Economy’, Proceedings of the 1988 One-Day Seminar organised by the Nigerian Economic Society, pp.1-17.

Obono, O., 2004, 'Globalization and Multiculturalism: An Essay on Contradictions', Ibadan Journal of the Social Sciences, Vol. 2 (1), September, pp. 87-105. 
Olutayo, A. O., 1991, 'The Development of Underdevelopment: Rural Economy of Colonial South Western Nigeria', Unpublished Ph.D. Thesis, Department of Sociology, University of Ibadan, Nigeria.

Olutayo, A. O., 2001, ‘The Subject Matter and Scope of Sociology', in Ikporukpo, C. O., ed., Government, Society and Economy: An Introduction to the Social Sciences, Ibadan: Faculty of the Social Sciences, University of Ibadan.

Olutayo, A. O., 2002, 'The concept of Mode of Production in the Analysis of Development', in Uche C. Isiugo-Abanihe, Austin N. Isamah and Jimi O. Adesina, eds., Currents and Perspectives in Sociology, Lagos: Malhouse Press, pp. 138-148.

Olutayo, A.O. and Bankole, 2002, 'The Concept of development in historical perspective: The Third World Experience', in Uche C. Isiugo-Abanihe, Austin N. Isamah and Jimi O. Adesina, eds., Currents and Perspectives in Sociology, Lagos: Malhouse Press, pp. 105-122.

Olutayo, L., 2001-2002, 'The Contributions of Ralf Dahrendorf to Sociological Discourse', Ibadan Journal of Humanistic Studies, Nos. 11 and 12, pp. 27-44.

Onimode, B., 1977, Neoclassicism, Keynesianism and Social Reality, Paper delivered at the Department of Economics, University of Ibadan, Ibadan, Nigeria, 16 March 1977.

Onimode, B., 1987, 'The African Crisis and Nigeria’, in Nzogola Ntalaja, Bade Onimode, Bernard Magubane, Harold Wolpe, Kempton Makamure, Fatima Babniker Mahmoud and Adoulaye Bathily, eds., Africa's Crisis, London: Institute for African Alternatives.

Onimode, B., 1988, 'The Political Economy of Privatization in a Depressed Economy', in Proceedings of the 1988 One-Day Seminar organised by the Nigerian Economic Society, pp.33-49.

Onoge, O. F., 1995, 'Africa and the Challenge of Empowerment', Annual Lecture Series 1 of the Empowerment and Action Research Centre (MPARC).

Oswaldo de Rivero, 2001, The Myth of Development: Non-Viable Economies of the 21st Century, London and New York: Zed Books.

Roxborough, I., 1979, Theories of Development, London: Macmillan Press.

Shayegan, D., 1992, Cultural Schizophrenia: Islamic Societies Confronting the West, London: Saqi Books.

South Centre, 1992, The United Nations at a Critical Crossroads: Time for the South to Act, Geneva: South Commission.

Stein, H., 1992, 'Deindustrialization, Adjustment, the World Bank and the IMF in Africa', World Development, (1) pp. 83-95.

Valentine, T., 1993, 'Botswana’s Financial Assistance Policy and the Indigenization of Industrial Employment', Centre for Economic Research on Africa, School of Business, Montclair State University, Upper Montclair, News Jersey (pdf version 2001).

Wilson, E. J. III, 1990, 'Strategy of State Control of the Economy: Nationalization and Indigenization in Africa', Comparative Politics, Vol. 22 (4), pp. 401-419. 